\title{
ENDOREDUPLICATION IN FLORAL STRUCTURE, VEGETATIVE AND FRUITS OF RED PITAYA WITH WHITE PULP
}

\author{
ENDORREDUPLICAÇÃO EM ESTRUTURA FLORAL, VEGETATIVA E FRUTOS DE \\ PITAYA VERMELHA DE POLPA BRANCA
}

\begin{abstract}
Thatiane Padilha de MENEZES ${ }^{1}$; Leila Aparecida Salles PIO² José Darlan RAMOS$^{3}$; Moacir PASQUAL ${ }^{4}$; Tesfahum Alemu SETOTAW

1. Doutora em Agronomia, Universidade Federal de Lavras - UFLA, Lavras, MG, Brasil. thatiagro@ yahoo.com.br; 2. Professora, Doutora em Agronomia, Universidade Federal de Lavras - UFLA, Lavras, MG, Brasil; 3. Professor, Doutor em Agronomia, Universidade Federal de Lavras - UFLA, Lavras, MG, Brasil; 4. Professor, Doutor em Agronomia, Universidade Federal de Lavras UFLA, Lavras, MG, Brasil. mpasqual@dag.ufla.br; 5. Doutor em Agonomia, Universidade Federal de Lavras - UFLA, Lavras, MG, Brasil.
\end{abstract}

\begin{abstract}
Endoreduplication is the change of cellular cycle that result DNA duplication without cell division and could result endopolyploid cells. This phenomenon is common in plants and animals and considered as evaluative strategy. Although endoreduplication reported in various plant species, the information about these phenomena in red pitaya is rare. Therefore, this work was done with the objective of studying the endoreduplication in Hylocereus undatus Haw. using flow cytometry analysis. In this study were used the tissue from the flower structure, fruits, roots, cladode, and thorns of the pitaya plant.To determine the DNA content approximately $50 \mathrm{mg}$ the sample of each treatment with Pisum sativum (the internal standard reference) were grind in plate of petri dishes contained $1 \mathrm{~mL}$ of cold Marie buffer to release the nucleus. The nuclear suspension was filtered through $50 \mu \mathrm{m}$ mesh. The nucleuses were colored with $25 \mu \mathrm{L}$ of $1 \mathrm{mg} / \mathrm{L} \mathrm{mL}$ of propidium iodide. For each treatment, three samples of 10 thousand nucleuses were analyzed in cytometry Facscalibur (Becton Dickinson). The content of nuclear DNA (pg) was estimated as the ratio between fluorescence intensity of the G1 nucleus of the standard and the G1nucleus of the sample multiplied by the quantity of DNA of the internal reference. In conclusion, the endoreduplication occurred in all part of the plants analyzed except in the aculeus and the roots. The analysis evidenced different index of DNA content in the tissues analyzed being observed up to four different ploidy levels. The phenomena of endoreduplication occurs in all parts of the plant analyzed except in aculeus and roots.
\end{abstract}

KEYWORDS: Flow cytometry. DNA content. Endopolyploidy. Hylocereus undatus Haw.

\section{INTRODUCTION}

Some decades ago, pitaya is cactaceae native to Tropical and subtropical America is unknown. But recently, itoccupied an increasing importance in exotic fruit market of Europe due to its exotism and organoleptic characteristics. The interest for the plant is recent and required more studies involving the agronomic, genetics and technology (MARQUES et al., 2011; BASTOS et al., 2006).

It is known that during the development of some plants the normal cellular cycle can be substituted by the altered cellular cycle where did not occur mitoses (CHEVALIER et al., 2011). This altered cellular cycle is denominated as endocycle or endoreduplication which occur the DNA duplication without separation of chromosomes and cytokinesis (de VEYLDER et al., 2011).

The endoreduplication can be initiated in various phases of plant development (de VEYLDER et al., 2011), thatcan result the variation of DNA content within the organism (COMAI, 2005).
Consequently the edoreduplicated cells are produced and this is one form of somatic polyploidy (NAGL, 1976; D'AMATO, 1984). The increase in the ploidy level can increase the metabolism and genetic redundancy that improve the productivity and quality of the plant (COMAI, 2005). It also accelerates the metabolism and improves the physiological functionsof the plant (BARROW, 2006).

This phenomenon is found in abundance among angiosperms that grows in adverse environmental conditions suggested as an evaluative advantage (BARROW; MEISTER, 2003).It's also reported in yeast and animals andbelieved to be the part of normal standard development or a response for physiological or genetic stimulus(EDGAR; ORR-WEAVER, 2001). It can also be associated with the increase in the size of the nucleus, cells, rate of metabolism, and cellular differentiation in variety of plants (SABELLI; LARKINS, 2008).

The endoreduplication can be proved using the flow cytometry technique that measures the physical and/or chemical characteristics of a single 
particle. In this technique, the measurements are done when the number of particles in suspension passed individually through the focus of light generating pulses of reflected light and the fluorescence that are collected are converted in to pulses of electric current by optical sensor. This principle can measure for example the DNA content of the cell (DOLEZEL; BARTOS, 2005).

The DNA content estimation has a number of application from basic research to plant breeding including estimating the genome size, evaluation of ploidy, detection of mixed ploidy and aneuploidy, evaluation of cellular cycle, study the chromosome elimination, cell separation, chromosome or organelles, among others (DOLEZEL; BARTOS, 2005).

Due to the importance of edoreduplication in plants and the absence of information about this phenomenon in pitaya fruit Brazilian , this work was done to study the occurrence of these phenomena in various parts of red pitaya plant through flow cytometry analysis with the quantification of the DNA content of these structures.

\section{MATERIAL AND METHODS}

The experiment was realized in pitaya plant with four years old maintained by a structure type of trellis installed in experimental site of the Horticulture Research of the Department of Agriculture, Federal University of Lavras, Brazil. Pitaya plants were used with five years of age in $3 \mathrm{x}$ 3 spacing, supported perpendicularly to the ground in eucalyptus stakes up to $1.80 \mathrm{~m}$.

The flow cytometer analysis was realized in floral structure of pitaya (sepals - the internal segment of perianth and petals - the external segment of perianth, stigma, anther, fillet, the bract of the pericarp, ovaries, ovary wall, ovules and pollen. The flowers completely opened with $32 \mathrm{~cm}$ length were used for analysis. In addition, tissues such as bract of epicarp, epicarp, mesocarp, endocarpoof the mature fruit (approximately $100 \mathrm{~g}$ ) and immature (approximately $30 \mathrm{~g}$ ), full seeds of mature fruits, thorns, cactus stems and roots were subjected for analysis. Three samples of different tissue taken from three different plants in each treatment were analyzed to verify the presence of endoreduplication.

To determine the DNA, content approximately $50 \mathrm{mg}$ of the tissue sample corresponding to each treatment together with Pisum sativum (the internal standard reference) were grinded in plate of petridish contain $1 \mathrm{~mL}$ of cold Marie buffer to release the nucleus. The nucleus suspension was aspirated through two gas chambers with the help of pipette of Pasteur and filtered using the $50 \mu \mathrm{m}$ mesh. The nucleuses were colored with the addition of $25 \mu \mathrm{L}$ of $1 \mathrm{mg} \mathrm{mL}^{-1}$ solution of propidium iodide for each sample. The samples were analyzed immediately after the preparation. For each sample, 10 thousand nucleuses were analyzed using the logarithmic scale. The analysis was realized using cytometer Facscalibur (Becton Dickinson) and the histogram is obtained with the software Cell Quest and analyzed statistically with the software WinMDI 2.8 .

The nuclear DNA content (pg) of the plants was estimated using the ratio of fluorescence cense intensity of G1 nucleus of the standard reference $(P$. sativum) and the G1 nucleus of the sample multiplied by the DNA content of the standard reference $(9.09 \mathrm{pg})$. The results obtained were submitted for analysis of variance (ANOVA) and the means were clustered using the Scott-Knott test, at $5 \%$ error probability by the software Sisvar (FERREIRA, 2011).

\section{RESULTS AND DISCUSSION}

The quantification of nuclear DNA through flow cytometer in a species is possible by comparing the pick formed by nucleus at G1 interface stage of cellular cycle of the standard reference (the material where its DNA content known) to the G1 pick of the sample to be analyzed. In the present study the samples in majority of the treatments presented more than one pick. Due to this reason, pea (Pisum sativum) was used as a standard reference since its pick did not overlays to the picks produced by the samples.

The coefficient of variation was below $2 \%$ for all the histograms that show high level of reliability of the results obtained in our study.

Some flower tissues (stigma, ovules, ovary wall, pollen), mature fruits (bract of epicarp, and seeds) and immature (tissue of mesocarp, bract of epicarp, mesocarp, and endocarp) did not show picks in the histogram obtained therefore it is not possible to quantify the DNA of these materials. In contras in other treatments we obtained histograms with good quality.

The treatments showed significant difference at $5 \%$ probability. The analysis of flow cytometer indicated the existence of various level of ploidy in different structure of the plant that evidenced the phenomena of endoreduplication. However, in aculeus and roots the histograms presented only one value for the DNA content represented by one pick in the histogram. The rest of 
Table 1. Index of DNA in pg of different structures of red Pitaya.

\begin{tabular}{lcccc}
\hline Treatment & ID Peak & ID Peak & ID Peak & ID \\
& 1 & 2 & 3 & Peak 4 \\
\hline Sepal - the external segment of perianth of the flower & $7.92 \mathrm{a}$ & $14.10 \mathrm{f}$ & - & - \\
Petal - the internal segment of perianth of the flower & $7.38 \mathrm{a}$ & $14.00 \mathrm{f}$ & $27.42 \mathrm{a}$ & $46.55 \mathrm{a}$ \\
Fillet & $7.33 \mathrm{a}$ & $14.29 \mathrm{f}$ & $27.43 \mathrm{a}$ & - \\
Anther & $7.45 \mathrm{a}$ & $14.06 \mathrm{e}$ & $26.89 \mathrm{a}$ & - \\
Stigmalobes & $7.02 \mathrm{~b}$ & $13.13 \mathrm{e}$ & - & - \\
Bract of epicarp of mature fruit & $4.46 \mathrm{c}$ & $9.03 \mathrm{~d}$ & $17.01 \mathrm{~b}$ & $32.70 \mathrm{~b}$ \\
Epicarp of mature fruit & $4.03 \mathrm{~d}$ & $8.60 \mathrm{c}$ & $15.85 \mathrm{c}$ & $31.07 \mathrm{c}$ \\
Epicarp of immature fruit & $3.50 \mathrm{e}$ & $6,97 \mathrm{a}$ & $13.20 \mathrm{~d}$ & $25,57 \mathrm{~d}$ \\
Endocarp of mature fruit & $4.05 \mathrm{~d}$ & $8.07 \mathrm{~b}$ & $15.94 \mathrm{c}$ & $32.24 \mathrm{~b}$ \\
Cladode & $7.22 \mathrm{~b}$ & $13.77 \mathrm{e}$ & & \\
Aculeus & $7.07 \mathrm{~b}$ & - & - & - \\
Roots & $4.02 \mathrm{~d}$ & - & - & - \\
\hline
\end{tabular}

*The means followed by the same letters in the column belong in the same groups and did not differ among themselves by the ScottKnott test, at 5\% error probability; ID: Index of DNA

It was possible to observe that the treatment with more than one pick presented a DNA content value a multiple ofthe least (Table 1) that proved the occurrence of endoreduplication, that result the level of the DNA content to be $2 \mathrm{C}$ in the first pick, $4 \mathrm{C}$ in the second, $8 \mathrm{C}$ in the third, and $16 \mathrm{C}$ in the fourth. This can be due to the fact that the values of the DNA content in the referred picks are the multiple among them.

According to Negron-Ortiz (2007), the phenomenon of endoreduplication is common in tissues of succulent plant and cactus. According to the author, the cactus under natural light presented very slow growth where endoreduplication is one of the mechanisms of adaptation of the plant to the extremely dray environmental condition and high temperature.

The flow cytometer analysis of somatic embryo, buds and callus of cactus Copiapoa tenuissima Ritt, forma monstruosa, cultured in vitro presented the nucleus with various ploidy in various tissues studied (LEMA-RUMINSKA, 2011). The five ploidy level with DNA content 2C, 4C, 8C, 16C and $32 \mathrm{C}$ were found but in in vivo condition the maximum level was 16C.

Probably, the endoreduplication was selected during the evolution for the benefit of the plant and organ development (CHEVALIER et al., 2011). This phenomenon is important for the development process such as cell maintenance, response to physiological conditions like pest attack and on DNA damage (DE VEYLDER et al., 2011). The endoreduplication occurs typically in large cells, metabolically active or highly specialized, however can also be found in cells that are not corresponding to this condition (Lee et al., 2009).

In plants, the occurrence of endoreduplication is common and documented in the endosperm of the cereal crops (SABELLI et al., 2009), cotton fiber (Gossypium hirsutum) (WILKINS et al., 2000), tomato fruits (CHEVALIER et al., 2011), nitrogen fixing legumes (KONDOROSI; KONDOROSI, 2004). It is also reported in the endosperm and cotyledon of the seeds in development (LEE et al., 2009). In the hybrid Doritaeenopsis, the nucleus isolated from leave, somatic embryo, and root tips presented different level of endoreduplication (PARK et al., 2010).

Some factors are being associated with the variation of DNA content in plants are diversity of the species, temperature, altitude, seed weight, leaves, anatomical characteristics, generation time, and growth rate (KNIGHT et al., 2005).

In the present work, the histograms generated through the analysis of flow cytometer showed various picks in different plant structures. In Figures 1 and 2 , it is possible to observe this variation in some plant parts of reproductive organs. 


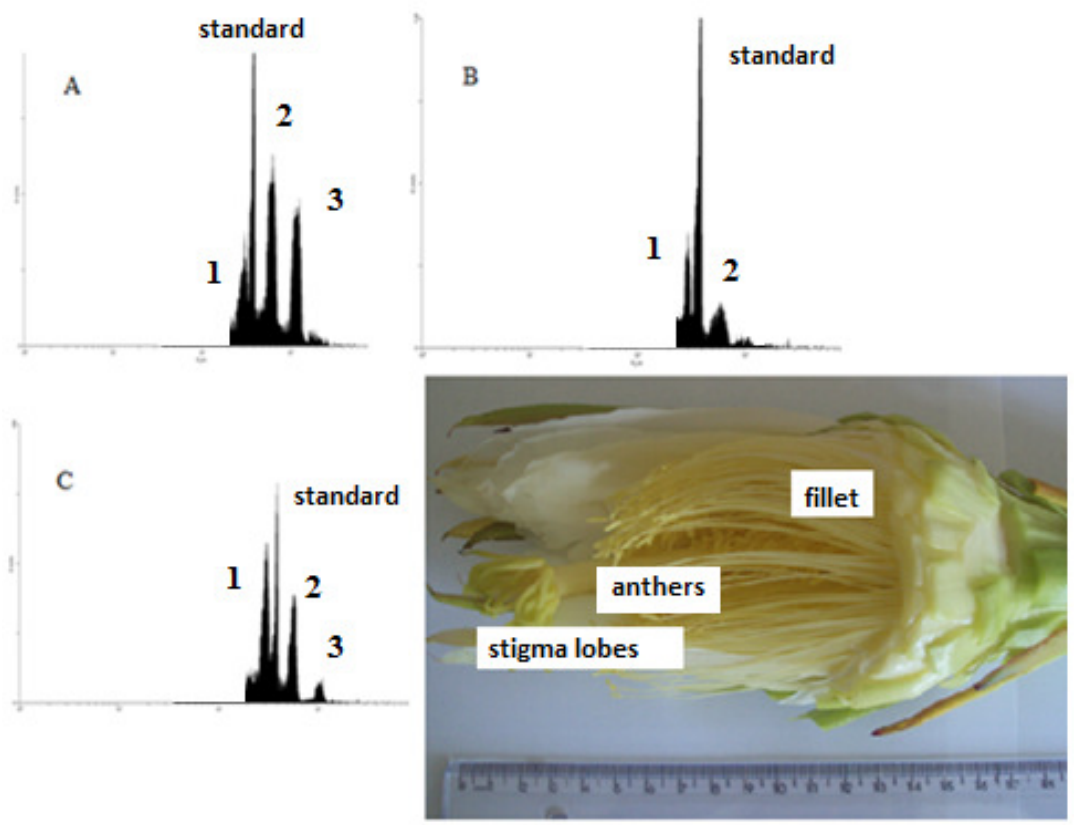

Figure 1. Histogram of the flow cytometer for the quantification of DNA. A) Fillet. B) Stigma lobes C) Anthers of open flower of red pitaya (Hylocereus undatus Haw), with pea (Pisum sativum L.) used as standard reference.

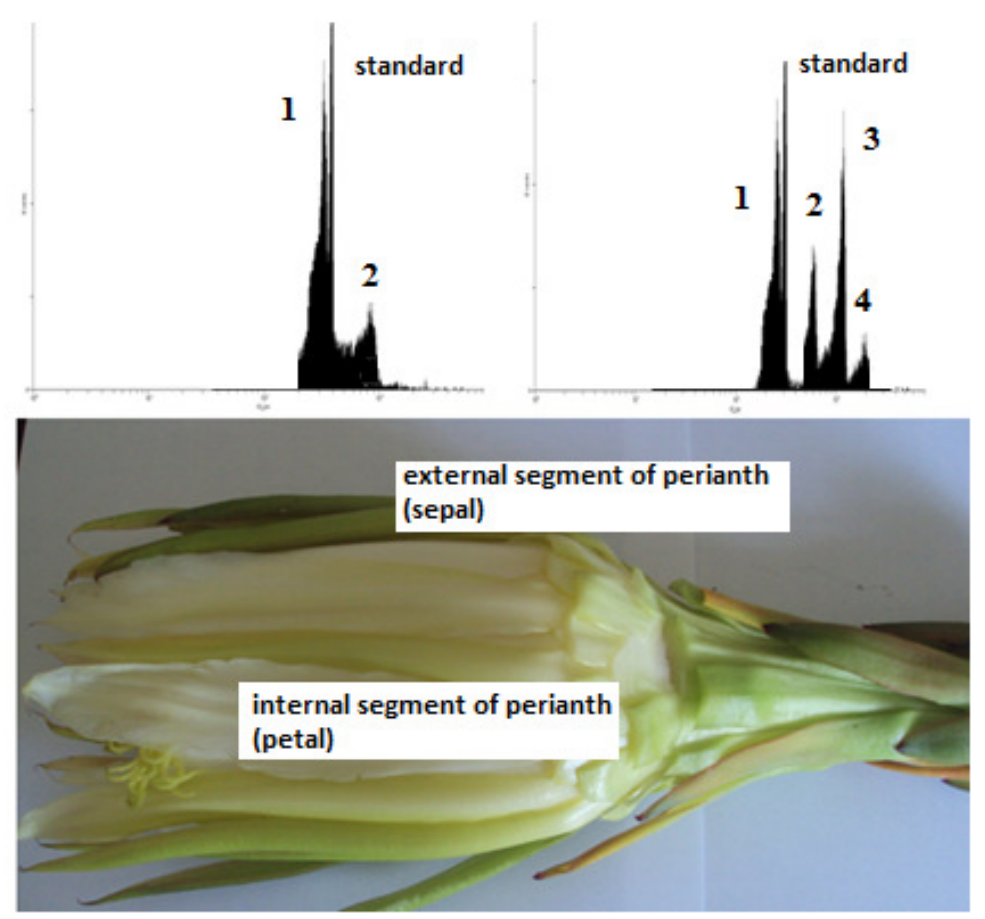

Figure 2. The histogram of flow cytometer for quantification of DNA.A) The external segment of perianth (sepal) B) internal segment of perianth (petal), of the open flower of red pitaya (Hylocereus undatusHaw), with pea (Pisum sativumL.) used as standard reference.

According to Chen et al. (2011) endoreduplication can be occurred in flowers of some species and reported significant level of endopolyploidy in different flower structure of orchids. This phenomena was observed in flowers of cabbage during its development (KUDO; KIMURA, 2001; KUDO; KIMURA, 2002) and in flowers of
Portulaca grandiflora reported high level of endopolyploidy in different parts of the flower (MISHIBA; MII, 2000). In studies about the fruit size of mutant apple Gala, Malladi and Hirst (2010) before fructification observed the association of the size of carpel and floral tubes with the increase in 
the cell numbers, large cell size and increase in ploidy through endoreduplication.

In the analysis realized in open flowers of $32 \mathrm{~cm}$ length the histogram generated from tissue of fillet, anther, and stigma lobes were presented in Figure 1. In the histograms of tissues of fillet and anther were observed three picks (1,2 and 3) represent different level of ploidy $(2 \mathrm{C}, 4 \mathrm{C}$ and $8 \mathrm{C})$ and one pick of reference standard used to calculate the quantity of DNA of the samples. These results proved that these materials presented three distinct ploidy levels. The analysis of the tissue from the stigma lobes evidenced two picks of the sample and one pick of the standard reference, suggested two level of ploidy $2 \mathrm{C}$ and $4 \mathrm{C}$.

In cactus and other succulent plants, endopolyploidy is related to the ecological mechanism important in situations with water deficit and high temperature (NEGRON-ORTIZ, 2007).
In histogram of Figure 2, it is possible to observe the internal tissue segment of perianth (sepal) presented two ploidy level and the external segment of perianth (petal) presented four distinct ploidy levels (2C,4C, 8C, and 16C).

Besides this, the quantity of DNA related to flower tissues vary from 7.02 to $7.92 \mathrm{pg}$ which is very high in relation to other tissue analyzed and this tendency was maintained in the subsequent picks.

Some tissues such as stigma, ovules, ovary wall, pollen, bract of epicarp of the mature and immature fruits, mesocarp tissue, bract of epicarp, mesocarp and endocarpof immature fruits and seeds are not produced pick in the histogram. Figure 3 illustrated the analysis of tissues from epicarp bracts where the pick observed in the histogram is in relation to the internal reference standard.
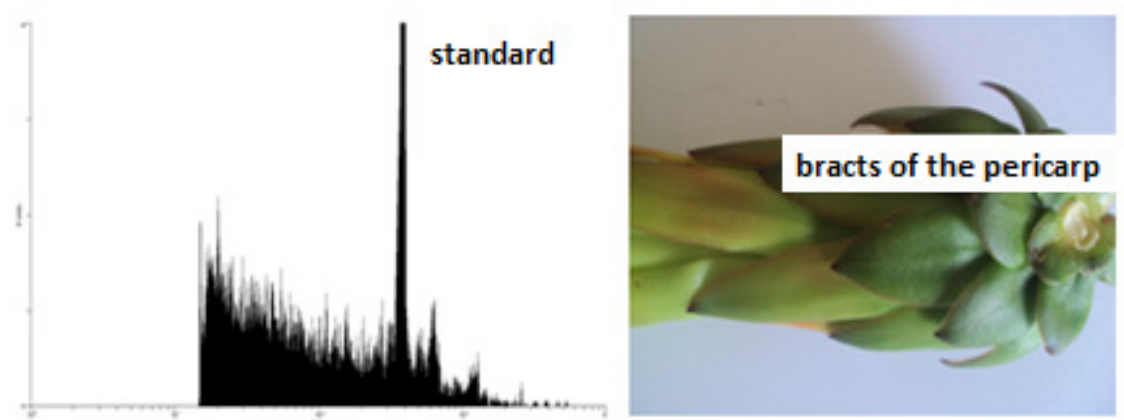

Figure 3. The histogram of flow cytometer for DNA quantification for sample tissue of bracts of the pericarp of the open flower of red pitay a(Hylocereus undatus Haw.) with pea (Pisum sativumL.)used as standard reference.

There are various hypotheses for not presenting the pick in the histogram in these materials; one of them is the formation of secondary metabolites in the tissue that interfere in the analysis. The extraction buffer may not be appropriate for the different tissues that form the treatments. Besides this, the presence of proper mucilage of the cactus can be influenced. The tissue of mesocarp of the fruits possess intense purple coloring that indicate the presence of anthocyanin. This pigment can also influence in the quality of the samples.
The cytometer analysis of the mature fruit (Figure 4) evidenced four distinct level of ploidy for epicarp, bract and endocarp, suggesting high index of endoreduplication. These four different levels of ploidy were verified still for the tissues of epicarp of the immature fruits and petals. From the analysis of the fruits, it is possible to verify the index of DNA are much lower than other tissues and vary from 3.5 to $4.46 \mathrm{pg}$ in the first pick following the tendency of the subsequent picks (Table 1). 


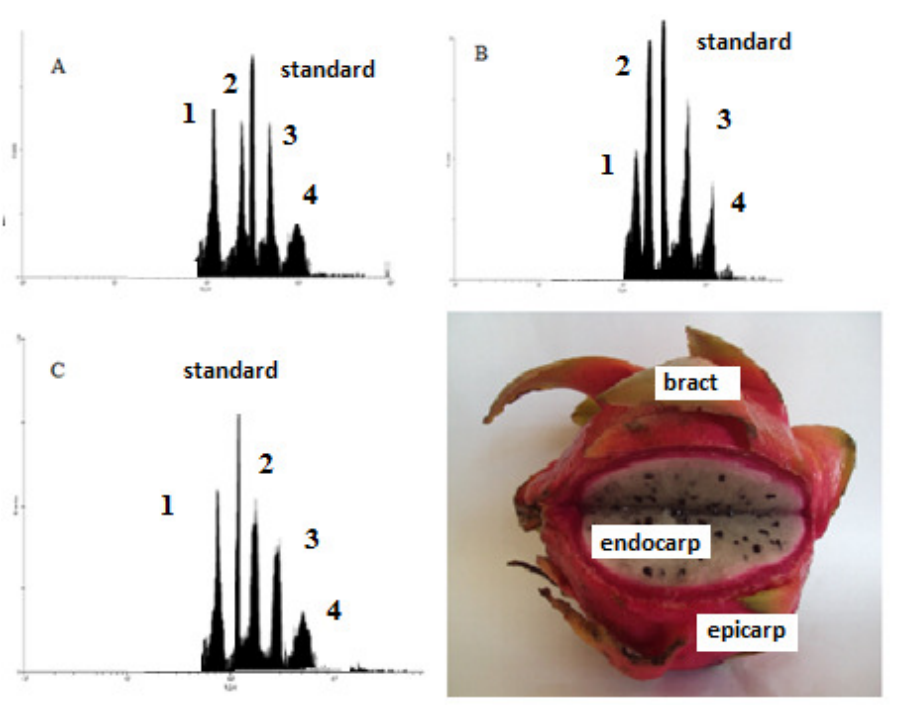

Figure 4. The histogram of flow cytometer for DNA quantification.A) Epicarp of the mature fruit. B) Bract of mature fruit. C) Endocarp of mature fruit of red pitaya (Hylocereus undatus Haw.), with pea (Pisum sativum L.) used as standard reference.

In recent studies, Bourdon et al. (2010) reported endoreduplication occurs in fleshy fruits that developed rapidly in 13 weeks with three to eight cycles of endocyclespecially in Solanaceae Cucurbitaceae. According to Marques et al. (2011), the complete maturation of the fruit of pitaya occurs 30 to 40 days after the flower opens. This fast development of the fruits presented a correlation with the phenomena of endoreduplication.

In tomato, the final cell size within pericarp of the fruit was correlated with the level of endoreduplication (CHENICLET et al., 2005). This phenomena appears not essential for the development of the fruit in apple (HARADA et al.,
2005), however, the endoreduplication was reported in apple variety Grande Gala during the flowering and initial growth of the fruit (MALLADI; HIRST, 2010).

The analysis of tissues of vegetative structures of red pitaya (cladode, aculeus and root) are presented in Figure 5. From the histogram it is possible to observe the phenomena endoreduplication occurred only in cladode with one pick representing possibly with diploid cells and other by tetraploid cells. In the coleus and roots endoreduplication was not observed since the samples showed only one level of ploidy (2C).
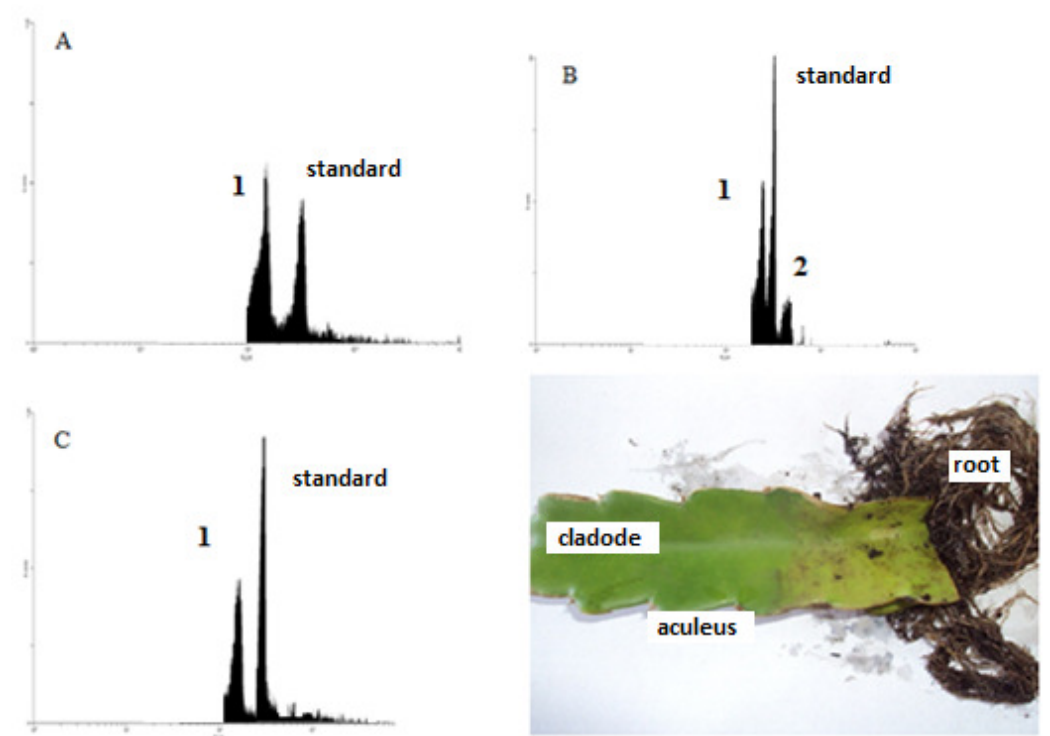

Figure 5. The histogram of flow cytometer for DNA quantification.A) Root. B) Cladode. C) Aculeus of red pitaya plant (Hylocerus undatus Haw.), with pea (Pisum sativumL.) used as standard reference. 
Frequently the endoreduplication occurred during the cellular differentiation that is highly specialized in its morphology such as cladode that is the modification of stalk. However, in the present work this phenomenon was occurred in various tissues. Although it is common in plants, the significance of endoreduplication still not well clarified. New studies are necessary to enlighten the transition of mitotic cellular cycle to cycle of endoreduplication in pitaya. It is possibly genetics and molecular mechanisms are involved in the phenomena of endoreduplication in this species.

\section{CONCLUSIONS}

The phenomena of endoreduplication occurs in all parts of the plant analyzed except in aculeus and roots.
The analysis proved different index of DNA content in the tissues and observed four level of ploidy.

The index of DNA is high in the floral structure and cladode. The aculeus, in the parts of fruits and roots was minimum.

\section{ACKNOWLEDGMENT}

We thanks the CNPq (Conselho Nacional de Desenvolvimento Científico e Tecnológico) and Capes (Coordenação de Aperfeiçoamento de Pessoal de Nível Superior) for its financial support to realize this work.

RESUMO: A endorreduplicação é uma alteração do ciclo celular, ocorrendo a replicação do DNA sem a divisão celular, podendo resultar em células endopoliploides. É um fenômeno comum em plantas e animais, sendo considerada uma estratégia evolutiva. Embora a endorreduplicação seja relatada em diversas espécies de plantas, as informações sobre este fenomeno em pitaia vermelha são escassas. Assim, objetivou-se com este trabalho estudar a endorreduplicação em Hylocereus undatus Haw. pela técnica de citometria de fluxo. Foram analisados tecidos de estruturas florais, de frutos, raiz, cladódio e acúleos de plantas de pitaia. Para a determinação do conteúdo de DNA, aproximadamente 50 mg de amostra de cada tratamento, juntamente com Pisum sativum (padrão de referência interno) foram triturados em placa de Petri contendo $1 \mathrm{~mL}$ de tampão Marie gelado para a liberação dos núcleos. A suspensão de núcleos foi filtrada através de malha de $50 \mu \mathrm{m}$. Os núcleos foram corados com $25 \mu \mathrm{L}$ de solução de $1 \mathrm{mg} / 1 \mathrm{~mL}$ de iodeto de propídeo para cada amostra. Para cada tratamento, três amostras de 10 mil núcleos foram analisadas em citômetro Facscalibur (Becton Dickinson). O conteúdo de DNA nuclear (pg) foi estimado utilizando-se a razão entre as intensidades de fluorescência dos núcleos G1 do padrão de referência e dos núcleos G1 da amostra, multiplicando-se esta razão pela quantidade de DNA do padrão de referência. Conclui-se que a endorreduplicação ocorre em todas as partes da planta analisada, exceto no acúleo e na raiz. As análises evidenciam diferentes índices de conteúdo de DNA nos tecidos, sendo observados até quatro diferentes níveis de ploidia. O fenômeno da endorreduplicação ocorreu em todas as partes da planta analisadas, exceto nos acúleos e raízes.

PALAVRAS-CHAVE: Citometria de fluxo. Conteúdo de DNA. Endopoliploidia. Hylocereus undatus Haw.

\section{REFERENCES}

BASTOS, D. C.; PIO, R.; SCARPARE FILHO, J. A.; LIBARDI, M. N.; ALMEIDA, L. F. P. de, GALUCHI, T. P. D.; BAKKER, S. T. Propagação de pitaya vermelha por estaquia. Ciência \& Agrotecnologia, Lavras, v. 30, p. 1106-1109, 2006.

BAROW, M. Endopolyploidy in seed plants. BioEssays, Massachusetts, v. 28, p. 271-281, 2006. http://dx.doi.org/10.1002/bies.20371

BAROW M.; MEISTER, A. Endopolyploidy in seed plants is differently correlated to systematics, organ, life strategy and genome size. Plant, Cell and Environment, Oxford, v. 26, p.571-584, 2003.

http://dx.doi.org/10.1046/j.1365-3040.2003.00988.x

BOURDON M, FRANGNE, N.; MATHIEU-RIVET, E.; NAFATI, M.; CHENICLET, C.; RENAUDIN, J. P.; CHEVALIER, C. Endoreduplication and growth of fleshy fruits. In: 'Progress in botany 71'. (Eds U Lüttge, W Beyschlag, B Büdel, D Francis) p. 101-132. (Springer: Berlin). 2010. http://dx.doi.org/10.1007/978-3-64202167-1_4 
CHEVALIER, C.; NAFATI, M.; MATHIEU-RIVET, E.; BOURDON, M.; FRANGNE, N.; CHENICLET, C.; RENAUDIN, J. P.; GÉVAUDANT, F.; HERNOULD, M. Elucidating the functional role of endoreduplication in tomato fruit development. Annals of Botany, Oxford, v. 107, p.1159-1169, 2011. http://dx.doi.org/10.1093/aob/mcq257

CHEN, W-H.; TANG,C-Y.; LIN,T-Y.; WENG,Y-C.; KAO,Y-L. Changes in the endopolyploidy pattern of different tissues in diploid and tetraploid Phalaenopsis saphrodite subsp. formosana (Orchidaceae).Plant Science, Ireland, v. 181, p.31-38, 2011. http://dx.doi.org/10.1016/j.plantsci.2011.03.006

CHENICLET, C.; RONG, W. Y.; CAUSSE, M.; FRANGNE, N.; BOLLING, L.; CARDE J. P.; RENAUDIN, J. P. Cell expansion and endoreduplication show a large genetic variability in pericarp and contribute strongly to tomato fruit growth. Plant Physiology, v. 139, p.1984-1994, 2005. http://dx.doi.org/10.1104/pp.105.068767 COMAI, L. The advantages and disadvantages of being polyploid. Nature Reviews Genetics. v. 6, p. 836-846, 2005. http://dx.doi.org/10.1038/nrg1711

DE VEYLDER, L.; LARKIN, J. C.; SCHNITTGER, A. Molecular control and function of endoreplication in development and physiology. Trends in Plant Science. Oxford, v. 16, p. 624-634, 2011.

D'AMATO, F. Role of polyploidy in reproductive organs and tissues. In: Johri, B.M. (Ed.), Embryology of Angiosperms. Springer-Verlag, New York, p. 523e 566, 1984. http://dx.doi.org/10.1007/978-3-642-69302$1 \_11$

DOLEZEL, J.; BARTOS, J. Plant DNA flow citometria and estimation of nuclear genome size. Annals of Botany, London, v. 95, p. 99-110, 2005. http://dx.doi.org/10.1093/aob/mci005

EDGAR, B. A.; ORR-WEAVER, T. L. Endoreplication cell cycles: more for less. Cell, v. 105, p. 297-306, 2001. http://dx.doi.org/10.1016/S0092-8674(01)00334-8

FERREIRA, D. F. Sisvar: a computer statistical analysis system. Ciência e Agrotecnologia, v. 35, n. 6, pp.1039-1042. 2011.

HARADA, T.; KURAHASHI, W.; YANAI, M.; WAKASA,Y.; SATOH, T. Involvement of cell proliferation and cell enlargement in increasing the fruit size of Malus species.ScientiaHorticulturae, Amsterdam, v. 105, p. 447-456, 2005. http://dx.doi.org/10.1016/j.scienta.2005.02.006

KNIGHT, C. A, MOLINARI, N. A, PETROV, D. A. 2005. The large genome constraint hypothesis: evolution, ecology and phenotype. Annals of Botany, Oxford, v. 95, p. 177-190, 2005.

KUDO, N., KIMURA,Y. Flow cytometric evidence for endopolyploidy in seedlings of some Brassica species, Theoretical and Applied Genetics, Heidelberg, v. 102. p. 104-110, 2001.

http://dx.doi.org/10.1007/s001220051624

KUDO, N.; KIMURA, Y. Nuclear DNA endoreduplication during petal development in cabbage: relationship between ploidy levels and cell size. Journal of Experimental Botany, v. 53, p. 1017-1023, 2002.

http://dx.doi.org/10.1093/jexbot/53.371.1017

KONDOROSI, E.; KONDOROSI, A. Endoreduplication and activation of the anaphase-promoting complex during symbiotic cell development. FEBS Lett.567, 152-157, 2004.

http://dx.doi.org/10.1016/j.febslet.2004.04.075

LEMA-RUMINSKA, J. Flow cytometric analysis of somatic embryos, shoots, and calli of the cactus CopiapoatenuissimaRitt.formamonstruosa. Plant Cell Tissue OrganCulture, Urbana, v. 106, p. 531-535, 2011. http://dx.doi.org/10.1007/s11240-011-9941-7 
LEE, H. O.; DAVIDSON, J. M.; DURONIO, R. J. Endoreplication: polyploidy with purpose. Genes \&Devlopment. v. 23, p. 2461-2477, 2009. http://dx.doi.org/10.1101/gad.1829209

MARQUES, V. B.; AMATO, R. A.; RAMOS, J. D.; ARAUJO, N. A. de, SILVA, F. O. dos. R. Fenologia reprodutiva de pitaia vermelha no município de Lavras, MG. Ciência Rural. Santa Maria, v. 41, p. 984-987, 2011. http://dx.doi.org/10.1590/S0103-84782011005000071

MALLADI, A.; HISRT, P. Increase in fruit size of a spontaneous mutant of 'Gala' apple (Malus x domestica Borkh.) is facilitated by altered cell production and enhanced cell size. Journal of Experimental Botany, v. 61, p. 3003-3013, 2010. http://dx.doi.org/10.1093/jxb/erq134

MISHIBA, K. I.; MII, M. Polysomaty analysis in diploid and tetraploidPortulacagrandiflora. Plant Science. Ireland, v. 156, p. 213-219, 2000.

NAGL, W. DNA endoreduplication and polyteny understood as evolutionary strategies. Nature. United States, v. 261, p. 614-615, 1976. http://dx.doi.org/10.1038/261614a0

NEGRON-ORTIZ, V. Chromosome numbers, nuclear DNA content, and polyploidy in Consolea (Cactaceaae), an endemic cactus of the Caribbean Islands. American Journal of Botany, Saint Louis, v. 94, n. 8 p. 1360 1370, 2007. http://dx.doi.org/10.3732/ajb.94.8.1360

PARK, S-Y.; YEUNG, E. C., PAEK, K-Y. Endoreduplication in Phalaenopsis is affected by light quality from light-emitting diodes during somatic embryogenesis. Plant Biotechnology Reports, v. 4, p. 303-309, 2010. http://dx.doi.org/10.1007/s11816-010-0148-x

SABELLI, P. A.; LARKINS, B. A. The contribution of cell cycle regulation to endosperm development.Sexual Plant Reproduction, Oklahoma, v. 22, p. 207-219, 2009. http://dx.doi.org/10.1007/s00497-009-0105-4

SABELLI, P. A., LARKINS, B. A. The endoreduplication cell cycle: regulation and function. In: Verma, D. P. S., Hong, Z. (Eds.), Cell Division Control in Plants. Springer-Verlag, Berlin-Heidelberg, p. 75e100, 2008.

WILKINS, T. A.; RAJASEKARAN, K.; ANDERSON, M. D. Cotton biotechnology.Critical Reviews in Plant Sciences, v. 19, p. 511-550, 2000. http://dx.doi.org/10.1016/S0735-2689(01)80007-1 